\title{
Hiperbola w reklamie i panegiryku
}

Piotr Michałowski 


\section{Piotr Michałowski}

\section{Hiperbola w reklamie i panegiryku}

Z estawienie porównawcze dwu form użytkowych nic wymaga wiçkszych uzasadnień; ich podobieństwo narzuca się samo - przede wszystkim poprzez charakter pochwalny i perswazyjny. Genetyczny związek oznacza wplywy jednokierunkowe: to panegiryk uksztaltował poetykę reklamy, a nie na odwrót. Można twierdzić nawet, że reklama jest współczesnym panegirykiem, w którym dawna adoracja osoby została przeniesiona na rzecz, czyli towar, a pośrednio - także na korzystającego z reklamowej oferty klienta. Na to pokrewieństwo gatunkowe wskazują zresztą teoretycy reklamy, między innymi wspomina o nim Ewa Szczęsna, nazywając reklamę wręcz „pastiszem panegirykı” ' - z czym jednak nie można się zgodzić, gdyż gatunki te różni cel przedsięwzięcia: w pastiszu chodzi o mimetyzm formalny, w reklamie o instrumentalne wykorzystanie formy.

Panegiryk to kategoria ponadgatunkowa, gdyż jego wyróżnikiem jest p o s t a w a p a n e g i r y c z 11 a, realizująca się w różnych gatunkach, takich jak: mowa, list, elegia, przednowa, dedykacja, epigranat, epicedium, epitafiım, epitalanium². W tym ıjęciu reklamę można dopisać do listy, uznając ją ponadhistorycznie po prostu za jeszcze jeden wariant panegiryku.

Związek ten warto jednak doprecyzować - wiąząc reklamę z kilkoma spośród skodyfikowanych przez Macieja Kazimierza Sarbiewskiego odmian panegiryku ${ }^{3}$ Najblizszy wydaje się g e n e t h l i a c o n - utwór opiewający nowo narodzone dziecię - wszak polecany w reklamie produkt zazwyczaj albo jest nowy, albo nowość udaje. Nierzadko owo radosne obwieszczanie narodzin przypomina też e p i b a te r i o n, czyli podziękowanie za dar zeslany przez niebiosa, ale tu analogia zależy już od wybranej techniki kreacji przedmiotu. Ponadto można

' E. Szczęsna, Poețka reklamy, Warszawa 2001, s. 126127.

2 It. Dziechcińska, Panegirvk, w: Slownik literatury staropolskicj. Srednioniecze, renesans, barok, red. T. Michatou'ska, Wroctan' 1998, s. 613.

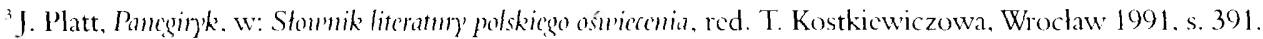


dostrzec - choć również w ograniczonym zakresie - dalekie pokrewieństwo z gatunkiem s o te r i u m, czyli gratulacjami z powodu uniknięcia nieszczęść, na przyklad wtedy, gdy chodzi o trafnie zastosowany proszek do prania, który nie powoduje utraty koloru tkaniny, lub użyty środek, zapobiegający zniszczeniu bębna pralki automatycznej. Albo wreszcie związek z e p in i c i o n e m, będącym pochwalą zwycięstwa odniesionego nad wrogiem lub dziękczynieniem za nie, a w tym wypadku chodzi o pokonaną grypę, ból, brud czy zarazki.

Istota panegiryku jest przesadnie wyrażona pochwała nie tylko osoby, ale także przedmiotu - jednak innego niż w reklamie, gdyż musi to być obiekt wielki i ważny: naród, państwo, miasto, kraj ${ }^{+}$. Najogólniej można więc transpozycję formy przedstawić tak: wysławianie zasłużonych postaci i obiektów przeszło calkowicie na przedmioty użytkowe - i to wale nie zasłużone, ale dopiero się zasługujące, gdyż chodzi z reguły o pojawiające się na rynku nowości, o wynalazki obiecujące lepszą przyszlość ich użytkownikom. Nastapiła zatem nie tylko wymiana obiektu pochwały, ale i przesunięcie wektora czasu — zwrot ku przyszłości. Panegiryk nastawiony jest przeważnie retrospektywnie, clioć może wymieniać i perspektywy dalszych sukcesów swego bohatera: panegirysta bowiem rzadko działa bezinteresownie, toteż pragnie zarówno pozyskać przychylność swego mecenasa, któremu utwór poświęca, jak i utwierdzić go w wyliczanych w dziele zaletach - zwlaszcza tych, które są dla laudatora korzystne. Natomiast reklama - jako promocja towaru - oddziałıje wylącznie prospektywnie, niezależnie od tego, że obietnicę traktuje jako spełniony fakt, a marzenie jak rzeczywistość. Można założyć nawet, iż bohaterem reklamy są whaśnie pragnienia odbiorcy, a nie ich przedmiot, który sluży tylko za medium ${ }^{5}$. Z kolei pojawiające się w reklamach postacie pośredniczą między tymi pragnieniami a produktem i sprowadzone zostają do wybranych ról, przede wszystkim roli autorytetu lub użythownika".

Wskazane różnice są szczególnie ważne dla zagadnienia techniki idealizacji, która ma w obu formach inny zarówno punkt wyjścia, jak i cel. Wychwalanie osoby w panegiryku wymaga jedynie uwypuklenia pewnych cech znanych już odbiorcy, wyolbrzymienia cnót i zaslug rzeczywistych, albo za takie oficjalnie uznanych (jak w przypadku panegiryków socrealistycznych); jest więc charakterystyką o wyraźnie określonej referencji. Natomiast w reklamie przesadna kreacja wizerunku przedniotu powstaje niejako ex mihilo, bez takiego punktu odniesienia, bez podstawy usytuowanej na zewnątrz wypowiedzi. Pisze Ewa Szczęsna:

Wypowiedź reklamowa wytwarza sytuację gry z tradycyjną formą panegiryku, gdzie najpierw musiała istnieć jednostka ze swoimi zasługami i zaletami, by dopiero później mogła pojawić się jej poclıwala. Wypowiedź reklamowa odwraca tę relację. Wykreowıje portret chwalonego, którym może być każdy, kto spełni okréslone warunki: skorzysta z uslugi, nabędzie towar. Reklama posługuje się

\footnotetext{
${ }^{+}$H. Dziechcińska, op. cit., s. 613.

'E. Szczęsna, op. cit., s. 132.

"Ibidem, s. 134.
} 
tu typową dla panegiryku hiperbolizacją, która odniesiona zostaje do przedmiotu oraz do tych, którzy wchodzą z nim w kontakt.

Niemniej trzeba zauważyć, że owo odwrócenic relacji nie dotyczy pierwszego obiektu pochwały, jaka jest prezentowany prodıkt, gdyż w tym wypadku sytuacja jest taka sama jak w panegiryku: towar także poprzedza egzystencjalnie reklanę, choć przypisywane mu cechy wyprzedzają możliwość ich doświadczenia przez odbiorcę.

Mniej oczywisty jest uz y t k ow y c ha rakter obu gatunków: panegiryk prócz utylitarnej pełni funkcję bliższą estetycznej. Rzeczywistość i nierzeczywistość powoływana w nim do życia dają się rozdzielić - przynajmniej w takim stopniu, w jakim obiekt pochwały znany byl wcześniej z doświadczenia autora lıb z innych wiarygodnycl źródeł. W reklamie natomiast fikcja zakrywa swą fikcjonalność, kreacja tworzy kopię często nieznanego jeszcze przedmiotu, która jest od razu jego interpretacją i zastępuje pierwowzór".

Różnica dotyczy także podmiotu wypowiedzi: w panegiryku jest on przeważnie jawnie autorski, natomiast w reklamie pozostaje ukryty, anonimowy, a tej niejawności towarzyszy sugestia, że to przedmiot wypowiedzi (zresztą często zantropomorfizowany) zachwala sam siebie. Nie ma więc w reklamie miejsca na apostrofę wyznaczającą relację ,ja — ty", a układ nadawca-odbiorca zostaje zbudowany inaczej. W przypadku panegiryku można mówić o adresie podwójnym: zwrocie do wysławianej osoby (u której podnosi samopoczucie) i do publiczności, mogącej pelnić rolę świadka i arbitra. W reklamic natomiast pierwszy adres jest pusty, a jego odpowiednikiem bylby zwrot do producenta (czyli zleceniodawcy reklamy), który nie miałby żadnego uzasadnienia ze względu na cel komunikatu. Główny kierunek działań perswazyjnych dotyczy bowiem potencjalnego nabywcy, a nie producenta.

Reklama - niezależnie od tego, że bliska jest poetyce konceptystycznej, barokowej, funkcjonalnie nawiązuje raczej do wzoru panegiryku oświeceniowe go, który mial kształtować autorytety i opinie, a poprzez pochwałę osoby (której odpowiednikiem jest towar) powinien nie tylko jej schlebiać, ale prezentować jako wzór osobowy; a więc spełniać cel dydaktyczny, wlączając się w progran narodowej edukacji”. Przypisywanie tak szlachetnego celu reklamie może się wydać nadıżyciem, jednak jej podobieństwo do panegiryku oświeceniowego jest wyraźne, gdy chodzi o skierowanie kommikatu na zewnątrz, poza układ „chwalący - chwalony", a w tym wypadku o apel do potencjalnego nabywcy, a więc — zaplanowanie instrumentalnego stylu odbioru".

Wynika stąd założenie doraźności i tym samym nietrwałości utworu. Stanisław Dąbrowski wprawdzie wymienia pośród wyznaczników panegriryku: aktualność tekstu (jego umoco-

\footnotetext{
7 Ibidem, s. 127.

* Ibidem, s. 131.

"J. Platt, op. cit, s. 392.

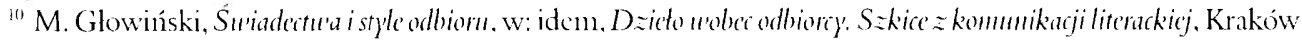
1998 , s. 147.
} 
wanie w teraźniejszości pozaliterackiej) i wlaśnie doraźnośćl" , ale ta ostatnia cecha wymaga komentarza. Panegiryk stwarza wizerunek monumentalny, zaprojektowany, jeśli nie na wieczność, to przynajmniej na stałe. Reklama również często absolutyzuje doskonałość rzeczy „po wszystkie czasy”, ale bardzo szybko bywa zdyskontowana przez następną reklamę z informacją o kolejnym ulepszeniu produktu; chwilowość i przelotność uzurpuje sobie prawo do wieczności w ,tu i teraz”. Czas w życiu przedmiotów plynie szybciej niż czas człowieka. Obowiązuje bowiem zasada permanentnej gradacji i krótkotrwałych awansów, chciało by się rzec: „eskalacja najlepszości”; reguła ta działa zarówno w porządku rozwojowym, gdzie dotyczy ulepszonych wersji tej samej rzeczy (produktu jednej firmy), jak i w rywalizacji wobec równocześnie wywyższanych rzeczy oferowanych przez konkurencję. Często więc pojawia się comparatiu'us i formuly w rodzaju ,jeszcze lepsze”, ,teraz ulepszone”, „teraz tańsze”, "nowe większe opakowanie za tę samą niską cenę"; przy czym stopień wyższy występuje zazwyczaj bez wskazywania kontekstı, bez dopowiedzenia tego, co implikuje każda „lepsza” postać produktı - na niedoskonałość wersji poprzedniej, gdyż byłoby to pośrednim przyznaniem się do winy po przedawnieniu „zbrodni”. Ten chwyt, sugerujący ciągły postęp bez wyraźnego punktu odniesienia do przeszłości, określić można jako „g ra da cję pozorna".

Obydwie formy nazwać można okolicznościowymi, choć zarazem jest to kategoria, która je różnicuje; gatunki te funkcjonują bowienn w okolicznościach zdecydowanie innych. Panegiryk, pisany i wygłaszany „z okazji”, umieszcza się w pewnej sytuacji: oficjalnej lub towarzyskiej; ma zatem wyznaczone miejsce i czas, a osoba poddawana adoracji zostaje wyeksponowana jako główny bohater w centrum czasoprzestrzeni. Inaczej działa reklama: pojawia się również sytuacyjnie, ale tylko „przy okazji” innych przedmiotów i zdarzeń, pasożytując na czasie i przestrzeni dla nich zarezerwowanych: ulicy, poczekalni dworcowej, ekranu telewizora, kolumny gazety, strony internetu. A więc z reguly działa z zaskoczenia, a celem dla odbiorcy staje się dopiero wtedy, gdy ten poszukuje informacji bardziej szczegółowych o reklamowanym produkcie.

Różnica dotyczy także t w or z y w a i k od u: panegiryk jest formą literacką, jakkolwiek znajduje swój odpowiednik w malarstwie portretowym, pomniku, muzycznym hymnie; reklamę uznaje się zazwyczaj za gatunek wielokodowy, w którym warstwa słowna współgrać może z elementami obrazowymi i muzyką, wytwarzając sens afirmatywny dopiero w ich interakcji ${ }^{12}$. Wybrana tu jako przedmiot analizy hiperbola obejmuje więc nie tylko przekaz werbalny, ale i na przykład obraz lub patetyzująca muzykę. Panegirykowi przypisany był styl wysoki: reklamę cechuje polistylistyczność: język poetycki miesza się z potocznym, a naukowy z magicznym ${ }^{13}$.

"S. Dąbrowski. O panegiryk'n, ..Przegląd Humanistyczny" 1966. z. 3. s. 106-107.

I: Niestety, autorka Poetyki rekluml' prawic milcząco zaklada wiclokodowość każdej reklamy.

${ }^{13}$ E. Szczęsna, op. cit.. s. 112. 
Wspólna obu formom jest oczywiście z a s a d a a m p l if i k a c j i (warto od razu przypomnieć, iż amplificatio znaczy zarówno „przesadzenie”, jak i „nieprawda”), która powodıje podobny konflikt między opisem a jego przedniotem. Według Dąbrowskiego w panegiryku zarówno same porównania, jak i przesada naruszają prawo „wlaściwego opisu”, czyli „wiernego i nie wykraczającego poza granice opisywanego obiektu od tworzenia go" ${ }^{+4}$. Oczywiście ta definicja wynika z idealistycznego założenia, iz słowo przystaje do rzeczy, toteż budzi wątpliwości jako nieuznająca odmiany opisu poetyckiego; niemniej trzeba się zgodzić, że te środki występują w panegiryku na usługach przesady, a przesada - na usługach konceptu ${ }^{15}$. A cała operacja zależy nie od bogactwa treści tkwiących w przedıniocie pochwały, ale odbywa się za sprawą „konceptystycznego wysitku, nastawionego na kompozycyjną rozbudowę utworu” ". Suponowana w tej definicji reguła: nieważne, kogo (co) się chwali, ale jak, otwiera możliwość włączenia w zakres dziedziny panegiryzmu także reklamy. Chodzi o swoisty przerost wypowiedzi ponad pragmatyczną konieczııść opisu przedıniotu. Status obiektu przedstawionego w wypowiedzi reklamowej został już określony; wydaje się bliższy quasi-sądom i fikcji literackiej, gdyż odniesienie do realnego przedmiotu zostaje zastapione albo przynajmniej przysłonięte jego kreacją, a więc niemożliwa jest mimetyczna weryfikacja opisu.

Różnica dotyczy e k on o m i i w y pow i e d z i, przy czym nie chodzi wylącznie o to, że panegiryk jest utworem relatywnie długim, a reklama krótkim na tle społecznej praktyki komunikacji, ale o różnicę strukturalną. Panegiryk to wypowiedź rozbudowana - niejako spiralnie, odśrodkowo - jak Peiperowski „poemat rozkwitający”. Slogan reklamowy (czyli dewiza, puentujące hasło) i opowieść (tzw. „elokwencja”) korzysta wprawdzie z konceptów literackich, w tym barokowych, ale zarazem dąży do skrótowości. Kondensacji sprzyja polimedialność reklamy, gdyż to, co przemilcza słowo, to może dopowiadać obraz lub muzyka. Stąd amplifikacja dokonuje się w sposób bardziej skokowy, w serii naglych skojarzeń, zderzeń, konfrontacji, i opiera się zwykle na jednym chwycie, na pojedynczej figurze. Wypowiedź jest więc krótka pozonnie, bowiem każde slowo możc otwierać całą opowieść-mit ${ }^{17}$. Także hiperbola musi tu być w jakiś sposób eliptyczna - przy czym nie chodzi wyłącznie o elipsę jako fígurę składniową.

Analizując porównawczo gatınki w aspekcie jednego tylko środka, za Michałem Gtowińskim przyjmuję tezę o centralnym usytuowaniu funkcjonujących w symbiozic poetyki i retoryki jako najbardziej rozwiniętej dziedziny wiedzy o wszelkim tekście, przydatnej w badaniu jego struktury ${ }^{18}$. W obu formach chodzi o deformację przedmiotu poprzez opis poetycki, a zasadą główną w tym przedsięwzięciu jest rozmaicie stosowana h i p e r b o l a — rządząca

\footnotetext{
${ }^{1+}$ S. Dąbrowski, op. cit., s. 44.

15 Ibidem. s. 50 .

in lbidem. s. 45.

17 E. Szczęsna, op. cit.. s. 1014, 106)

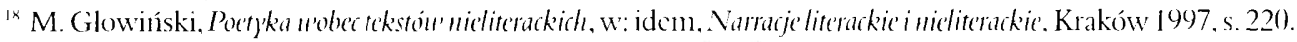
Pośród próbopisu reklany z perspektywy retoryczncj wymicnić trzcba pracę: P. I 1. Lewiniski. Retonjka reklam)' Wroclaw 1999.
} 
wykorzystanymi figurami (choć w wielu systematykach sama uznawana za figurę per immıutation''m myśli, stów lub trop, sytuujący się obok alegorii, ironii, emfazy i synekdochy) ${ }^{19}$. W obu przypadkach deformacja ma ten sam kierunek: waloryzuje przedmiot dodatnio.

Maciej Kazimierz Sarbiewski (w De perfecta poesi) wyróżnia dwa topoi jako zespoły argumentów, za pomocą których można podnieść rangę clıwalonego obiektu:

1. stwierdzenie, ze obiekt ten przyćmił wszystkie pozostałe, dotychczasowe;

2. że nie tylko dawne obiekty zashıgują na szacunek, ale i ten im dorównuje ${ }^{20}$.

Są to dwie możliwości nobilitacji, różniące się stosunkiem chwalonego do jego tła. Nie ulega wątpliwości, że w reklamie bardziej pożądana jest metoda pierwsza, zakładająca wyłączność oferowanego produktu, a nie jego równoprawność w szeregu wyrobów podobnych. Chodzi zatem o odmianę hiperboli zwaną h y p e r o c h e. Obiektem równoczesnej degradacji jest na przyklad „zwykły proszek” — skazany na anonimowość przez prawo, które zabrania mówić źle o konkurencji, ale ta ogólnikowa formula wystarcza, bo znaczy tyle co „wszystkie pozostate proszki są gorsze". Celem jest wywyższenie maksymalne i bezwzględne, zakładające wyłączność i wyklıczenie rywalizacji, wytworzenie wokół przedmiotu bezpiecznej pustki. Druga metoda stosowana jest rzadziej, choć zarazem zostaje włączona w bardziej wyrafinowaną strategię perswazji i można ją wiązać z retoryką wstępu - exordium. Tym sposobem dokonywana promocja towaru, udająca zaledwie walkę o równouprawnienie, łączy bowiem topos skromności z argumentami pochodzącymi z dyskursu demokracji, na przykład „prawie 80 procent mieszkanek Trójmiasta nie widzi różnicy” — gdy chodzi ojakiś tańszy proszek do prania, który okazıje się równie dobry jak podobne doń proszki drogie i renomowane.

I dealiza cja przedmiotu wymaga nie tylko wyolbrzymienia cech pozytywnych, ale i złagodzenia, zatarcia lub wręcz pomijania cech negatywnych. Symetrycznie do hiperboli pojawia się więc li t o t a, a istotną rolę w tym procesie odgrywa także e u fe $\mathrm{m}$ i z $\mathrm{m}$. W panegiryku wydaje się to prostsze: można wybierać cechy, o których się mówi, natomiast inne, niepożądane (na przykład powszechnie znane zbrodnie dokonane przez slawionego władcę) zwyczajnie przemilczać. Na ogól zresztą osoba poddawana laudacji ma tyle zalet, stanowiących dogodny punkt zaczepienia, że można się skupić wylącznie na nich, pomijając niestosowne szczególy charakterystyki lub je nazywając inaczej, na przykład motywując twarde rządy tyrana jego „stanowczością”, a odporność na imnowacje w sposobie rządzenia, których domaga się lud — „żelazną konsekwencją” (zamiast, powiedzıny, „oślim uporem”). W przypadku reklamy proces idealizacji okazuje się trudniejszy. Promowany towar miewa bowiem różne przeznaczenia, nie zawsze tak szlachetne jak perfunny, torty czy inne zbytki, które pochwalić łatwo. Wobec przedmiotów do użytku bardziej przyziemnego sięga się więc do formul peryfrastycznych, na przyklad w odniesieniu do fizjologii kobiecej stosuje się eufemizm,

1" J. Zionck, Retoryka opisou'a. Wroclaw 1990, s. 189-193.

21) I. Dzicchcińska, op. cit.. s. 613. 
mówiąc o „tych trudnych dıriach”, a w warstwie obrazowej podpaska zabarwia się antyrealistycznie: na niebiesko.

W reklanic większą niż w panegiryku rolę odgrywa poró w 11 a n i e przesadnie skontrastowanej rzeczywistości s p r ze d pojawienia się przedmiotu ze stanem po. Ma to podkreślać niezbędność produktu. Przedstawia się więc najpierw miejsce w świecie naznaczone jego b r a k i e m, a świat bez niego zostaje wykreowany jako niepehny, smutny, nieprzyjazny, wręcz nienadający się do życia. Owo absolutyzujące kontrastowanie uruchamia zatem hiperbolę po obu stronach porównania: wyolbrzymione zostaje zarówno nowe dobro teraźniejszości, jak i minione zło - czyli wspomniany brak. Powiększeniu podlega drobne nieszczęście (na przyklad dokuczliwość komara czy kamień i rdza na kranie), po to, by można było uzasadnić wage następującego po nim ratunku. Dokonuje się tu

... hiperbolizacji spraw dnia codziennego, czyniąc z plamy na blızce, kamienia osadzającego się na urządzeniach sanitaruych czy łupieżu kluczowy problem, od którego rozwiązania zależy szczęście jednostki. Codzienne niedogodności podniesione zostają do rangi problemów prezentowanych jako tragiczne ${ }^{21}$.

Dlatego w bliskim sąsiedztwie sytuıje się powaga i parodia, ścierają się opozycyjne style i gatunki. Zagrożenie tragiczne musi jednak zamiast katastrofy znaleźć rozwiązanie w komediowym happy cndzie. Motywom infernahnym przeciwstawiana jest rzeczywistość niemal rajska. Pojawiający się jako deus ex machina produkt bywa „zbawienny” albo posiada moc „magiczną" i zostaje umieszczony pośród zjawisk nadprzyrodzonych. Reklama utożsamia bowiem to, co użytkowe, $z$ tym, co idealne, i przenosi ze sfery profanmm do sacrum ${ }^{22}$.

Przejawia też skłonność do oddziaływania wstrząsowego: krótkiego, prędkiego i mocnego, sprawiając, że każde powiadomienie o produkcie chce być nie tylko informacją, ale od razu sensacją. Dlatego nowy środek czystości powoduje albo cud, albo przynajmnicj .przewrót w sprzątaniu”. Nie „ulatwienie”, nie „usprawnienie”, nie „przyspieszenie”, ale wlaśnie od razu „przewrót”. Określenia adekwatne wydają się bowiem zbyt słabe; regutą jest natomiast

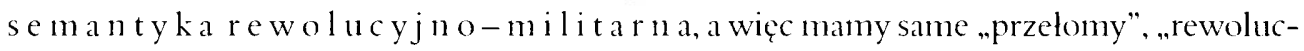
je" i „przewroty" - choćby w zwalczaniu brudu i zarazków. W najgorszym razie - jedynie „sukcesy”. Znacznic częściej jednak zdarza się tu „cud”, a przynajmniej zaburzenie osobowości: batonik to „obsesja smaku” a po spożyciu chrupek — jak twierdzi na plakatach znany kierowca rajdowy Krzysztof Holowczyc - „przestajesz być sobą”. Ze słownictwem rewolucyjnym dobrze współbrzmi se ma n t y k a t ra n s gre s ji. Obydwa sposoby renominacji zjawisk sugerują, ze chodzi o jakiś stan wyjątkowy, dla którego zwykłe gramatyczne metody stopniowania już się wyczerpaly, a niemożliwość eskalacji superlatywów, jakimi adoruje się reklamowany produkt, sprawia, że dalsze zmiany ilościowe muszą oznaczać już zmianę jakościowa.

2 E. Szczęsna. op. cit.. s. 146.

Ibidem, s. 115. 
Pisząc o stosowanych ś ro d k a ch a r t y s t y c z 1 y c h, ich oryginalności i zarazem konwencjonalności, można odnieść także do poetyki reklanny trafną formułę Dariusza Śnieżki, zaproponowaną wobec panegiryku: utwór sytuuje się „między klauzulą wielokrotnego użytku a klauzulą najwyższego uprzywilejowania"23. Jak wiadomo, w panegiryku, prócz wyrafinowanych niepowtarzahnych konceptów pojawiały się t o p o s y. W reklamie również da się je z łatwością wskazać, o czym świadczy choćby wspommiana już topika: magii, cudu, raju. Zdarza się to nader często - mimo wyścigu oryginalności i eskalacji konceptu, która jest chorobą calej branży reklamowej.

Najprostszą formą przesadnego opisu przedmiotu jest użycie epite tu metafor y c z n e g o, na przykład wyrażenie „magiczny smak”, albo kreacja poprzez słowo w asocjacji z obrazem, na przykład odczucie świeżości, jakie daje guma do żucia, zestawione z pejzażem lodowcowym. Nazwać to można hiperbolą in terse miotyczną. Przymiotniki określające przedmiot mogą układać się w serie, enumeracje, najczęściej triadyczne (a więc sugerujące doskonałość) i komplementarne (na przyklad: zapach dezodorantu może być zarazem „trwały, męski i zniewalający”), natomiast rzadziej są ułożone w gradację. Ta ostatnia figura służy retardacji i przygotowuje puentę, która po przewidywalnych treściach wyrażonych w stopniu równym i wyższym powinna zaskoczyć niespodziewanym finalem w superlatywie. Na przykład:

Na czynność X potrzebujesz 3000) sekund, na czynność Y przeznaczasz codziennie 30 sekund. My wykonujemy czynność $Z$ z dokładnością do 1 sekundy!

Ulubioną formą hiperbolijest, „uży c i e porów na nia s topnia wyżs zego ce c hy z da ną c e chą - typu "bielsze niż śnieg», "miód nie tak słodki», a traktowane w retoryce jako odmiana katachrezy"2+. Obydwa te przykłady (a celowo zostały wybrane porównania najbardziej zużyte) wskazują na proweniencję chwytu - jako komplementu ze staropolskiego madrygału czy właśnie panegiryku. A więc w tym kontekście spójrzmy na przykład z reklamy: „wyobraźnia silniejsza niż dynanit” — o tyle przewrotny, że samo hasło nie spehinia zawartej w sobie tezy czy groźby, bo nie tylko nie wybucha, ale nawet za bardzo już nie porusza. Z latwością można wskazać podobne hiperboliczne me t a for y w sloganach: „bounty — smak raju” czy „porwie cię ocean przyjemności”.

Warto jeszcze zwrócić uwagę na tendencję nadużywania pr zed ros tkó w z w i e lok r o t n i e n i a - zresztą widoczną nie tylko w praktyce reklamy, ale i w całej sferze handlu i wytwórczości. Zamiast zwyklych „sklepów” czy „marketów” powstają tylko: „mega-”, „giga-”, ,hiper-” lub „super-markety”, a obnizka ceny zaledwie o 30 groszy to już „superpromocja”. Nie ma ograniczeń co do zakresu stosowania tych określeń - choć nazwy adekwatne

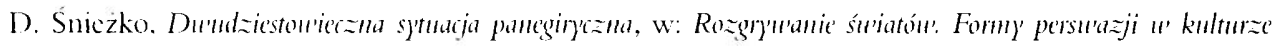
"rspótczesncj. red. I. Iwasiów: J. Madejski. Szczecin 1994, s. 69.

it J. Zionck. op. cit. s. 192. 
sajedynie do nielicznych obiektów. Byle sklepik chce być „salonem” „centrum”, a ponadto gigantomania rodzi takie instytucje jak ,.studia” i ,światy”: „studio rzęs” czy „świat lazienek”. Dotyczy to również wyolbrzymienia dokonywanego w samych markach wyrobów, na przykład lazienkowa suszarka do rąk nazywa się „Tornado”, a spluczka „Niagara”. Zjawisko to można wiązać z e m fa zą.

Zdarzają się wreszcie t a utologie, wskazıjące granice hiperbolicznej pochwaly, na przykład w pytaniu o działanie proszku do prania: „czy biel może być jeszcze bielsza?” Potrzeba wyolbrzymiania spełnia się na przekór logice i prawidłom języka, na przykład zakłada się, że „doskonałośc” podlega stopniowaniu i może być jeszcze wzmocniona przymiotnikiem, gdy mowa o serku „absolutnie doskonalym”. Na uwagę zasługują sytuacje, w których hiperbolizuje się przedmiot poprzez sugestię niewyrażalności, na przykład kostkę bulionu opisuje formuła: „to więcej niż bulion”. Zróżnicowana może więc być śmiałość hiperboli, a ujmując to zjawisko również tautologicznie, można powiedzieć, że sama przesada bywa mniej albo bardziej przesadna.

Wydaje się, że panegiryk, niezależnie od wybujałości konceptu, ustępuje pod tym względem reklamie - być może dlatego, że funkcjonując jako utwór okolicznościowy niekiedy staje się komunikatem prywatnym, a reklama nie jest nim nigdy (choć bywa na taki stylizowana). W panegiryku niedopuszczalne jest przekraczanie pewnych granic, poza którymi pochwała przeradza się w ironię, a takie zagrożenie przynoszą choćby nazbyt śmiałe paradoksy. Natomiast możliwość zastosowania absurdı w reklamie wynika z braku podobnych ograniczeń, gdy chodzi o zachowanie delikatności wobec adresata, a jedynym kryterium użyteczności tej figury jest skuteczność perswazji. Z tego względu w reklamie zdarza się więcej swobody logicznej niż w panegiryku. Opiewany whadca czy mecenas może być najwyżej „boski”, ale jego czyny nie mogą być uznane na przykład za „bardziej ludzkie” niż on sam; tymczasem ketchup bez przeszkód staje się „bardziej pomidorowy niż pomidor”. Twierdzenie o większej zawartości surowca w przetworze niż w nim sanym przekracza śmiałość słynnego komediowego konceptu o „badaniu zawartości cukru w cukrze”, ale przyciąga uwage odbiorcy wlaśnie swą paradoksalnością. Zresztą ten ironiczny koncept sparafrazowano już przez napis mmieszczony na opakowaniach cukru: „100 procent cukru w cukrze”, a więc whaśnie w reklamowym sloganie.

Chętnie eksploatowane w rẻklamach wątki nadprzyrodzone również podlegać mogą podobnym operacjom - pojawiając się w oksymoronicznych epitetach i antytezach. Wspomniany ketchup opisać można antytetyczną parą oksymoronów — jako: „niebiański smak piekta” i zarazem „piekielny smak nieba”. Opozycyjne sfery pozaziemskie i wiekuiste zderzone zostały w grze hiperbolicznych antytez — mieszając dobro ze złem — zresztą zgodnie z inną reklamową formulą: „dwa w jednym”.

Przykłady z ketchupem wydaja się równie bliskie reklamowej praktyce, co jej parodii. Tymczasem pierwszy pochodzi z prawdziwej reklamy, drugi jest cytatem z komedii Domana Nowakowskiego Ketchup Schroedera - o poecie robiącym karierę w firmie reklamowej. Granica dzieląca panegiryk od jego parodii bywa równie cienka (a za przykład moga posłużyć socrealistyczne wiersze Gałczyńskiego), niemniej w znacznym stopniu zależy od kontekstu ma- 
cierzystego: konwencji epoki i osiągnięcia równowagi trudnych do pogodzenia cech cudowności, wiarygodności i lojalności. Nienalą rolę odgrywają tu czynniki indywidualne: osobowość nadawcy i adresata; wiele zależy bowiem od poziomu tolerancji bohatera względem autora panegiryku, jego gustu estetycznego, wreszcie poczucia humoru. Wszak nieunikniony w każdej „przesadnie przesadnej” pochwale bywa whaśnie humor — albo jako efekt uboczny, albo zamierzony. Trudno przypuścić, by panegiryki były adresowane zawsze do ludzi w tę cechę niewyposażonych — przynajmniej w takim stopniu, że nie odgadywali przesady w przesadzie. Sa jednak bardzo subtelne różnice między kpiną z opisywanej amplifikacyjnie osoby a kpiną z konwencji panegiryku. A tolerancja wobec tej drugiej wydaje się wręcz warunkiem funkcjonowania panegiryzmu, zasadą, umożliwiającą uprawianie w sposób poważny formy, którą już w założeniach do literatury „poważnej” zaliczyć trudno.

Reklama granicę powagi i niepowagi pochwały likwidıje. Wchłania więc swych wrogów, w tym także kpinę z siebie: antyreklamowe, ironiczne i komiczne parafrazy, i śmiało gra z dynamiczną świadomością konwencji — prześcigając bądź doganiając ją, a zarazem dystansıjąc się do swej przeszłości. Nie chodzi bowiem o to, by odbiorca uwierzył w absurdalne nieraz porównanie, ale o to, by w swej świadomości utrwalił pozytywne skojarzenie obydwu elementów: sloganu z towarem - na zasadzie reagowania Pawłowa. Przykład z „cukrem w cukrze” dowodzi, iz najłatwiej zapamiętywane są właśnie dowcipy, i dlatego stanowią one w reklamie najlepszy ,surowiec wtórny”. Znany wiersz Wislawy Szymborskiej Prospekt - zresztą znacznie wyprzedzający kapitalizm i epokę wszechobecności reklanny w polskich mediach — jeśli usunąć zeń ramę ironii, ale pozostawić najśmielsze hiperbole, w wielu partiach może być uznany przez niezorientowanego w poezji czytelnika nie tylko za pastisz gatunku, ale wręcz cytat:

Jestem pastylka na uspokojenie.

Działam w mieszkaniu,

skutkuję w urzędzie,

siadam do egzaminów,

staję na rozprawie,

starannie sklejam rozbite garnuszki —

tylko mnie zażyj,

rozpusśc pod językiem,

tylko mnic połknij,

tylko popij wodą.

Wiem, co robić z nieszczęściem,

jak znieść złą nowinę,

zmniejszyć niesprawiedliwość,

rozjaśnić brak Boga,

dobrać do twarzy kapelusz załobny.

Na co czekasz -

zaufaj chemicznej litości. (...)

Trudno bowiem reklamę sparodiować skutecznie - to znaczy tak, by się nie stala po prostu jeszcze jedną reklama. 